\title{
Ventilation of rats with room air is more adequate than ventilation with pure oxygen
}

\section{Ventilar ratos com ar ambiente é mais adequado do que ventilar com oxigênio puro}

\author{
Marcus Vinicius Henriques de CARVALHO ${ }^{1}$; André José FRUCHI ${ }^{1}$; Evaldo MARCHI ${ }^{1}$ \\ ${ }^{1}$ Faculdade de Medicina de Jundiaí, Departamento de Cirurgia, Jundiaí - SP, Brazil
}

\begin{abstract}
The present study objective was to determine whether ventilation of rats with room air is possible and whether this technique has advantages when compared to pure oxygen ventilation. Twenty rats were divided into two groups of ten animals each. In one group, the animals were ventilated with cylinder of compressed air, 0.21 of oxygen, (air group), while the other group animals were ventilated with cylinder of compressed oxygen, assumed 1.00 of oxygen, (O2 group). Blood gas parameters and oxygenation index were compared between groups. The O2 group had hyperoxia at the beginning and end of artificial ventilation. The $\mathrm{PaO} 2$ were adequate in animals of air group. No significant difference in $\mathrm{PaCO} 2$ was observed between the two groups at the beginning or end of mechanical ventilation. The mean oxygenation index ( $\mathrm{PaO} 2 / \mathrm{FiO} 2 \mathrm{ratio})$ was significantly higher in the air group compared to the $\mathrm{O} 2$ group at the beginning and end of artificial ventilation $(5 \mathrm{~min}: \mathrm{p}<0.001$ and $60 \mathrm{~min}: \mathrm{p}<0$. In conclusion, ventilation of rats with room air is more advantageous than with pure oxygen since it permits adequate oxygenation without causing hyperoxia.
\end{abstract}

Keywords: Ventilation. Oxygen. Air. Rats.

\section{Resumo}

O presente estudo investigou se a ventilação de ratos com cilindros de ar comprimido é possível e se esta técnica seria melhor do que o procedimento de ventilação com cilindros de oxigênio comprimido. Vinte ratos foram divididos em dois grupos de dez animais cada. Em um grupo os animais foram ventilados com ar ambiente e o outro grupo foram ventilados com oxigênio puro. Parâmetros dos gases sanguíneos e o índice de oxigenação foram comparados entre os grupos. $\mathrm{O}$ grupo dos animais ventilados com oxigênio puro teve hiperóxia no começo e no fim da ventilação mecânica. A $\mathrm{PaO} 2$ ficou adequada nos aniamais ventilados com ar ambiente. Não houve diferença significativa na $\mathrm{PaCO} 2$ entre os dois grupos no começo e no fim da ventilação mecânica. A média do índice de oxigenação (razão $\mathrm{PaO} 2 / \mathrm{FiO} 2$ ) foi significativamente mais alta no grupo de ar ambiente quando comparado com o grupo do oxigênio puro no começo e no fim da ventilação mecânica ( $5 \mathrm{~min}$ : $\mathrm{p}<0,001 \mathrm{e} 60 \mathrm{~min}$ : $\mathrm{p}$ $<0,002)$. Em conclusão, ventilar ratos com ar ambiente é mais vantajoso do que quando realizado com oxigênio puro porque permite oxigenação adequada sem causar hiperóxia.

Palavras-chave: Ventilação. Oxigênio. Ar. Ratos. 
Correspondence to:

Marcus Vinicius Henriques de Carvalho

Faculdade de Medicina de Jundiaí, Departamento de Cirurgia

R. Francisco Telles, 250

CEP 13202-550, Jundiaí, SP, Brazil

e-mail: marcus.carvalho@sbccv.org.br

Received: 06/04/2015

Approved: 03/10//2016

\section{Introduction}

About 50-100 million vertebrate animals are used annually for scientific purposes, with mice and rats accounting for $80 \%$ of all species used (HEDENQVIST, 2008). Rats are commonly employed in scientific research, particularly experimental surgery, because they are easily obtained and because of their low cost and resistance to infections (O'NEIL et al., 1999). In addition, their small size permits easy handling and care in the animal house. Several experiments employing small animals require artificial ventilation, a fact that has encouraged improvement of the technique in these animals.

Mechanical ventilators that promote pressurecontrolled inspiratory/expiratory cycles are widely used for animal ventilation in experimental studies since they are easy to use and are more accessible because of their low cost. Reservoirs of pure oxygen $\left(\mathrm{O}_{2}\right)$ instead of a mixture of gases (blender) are commonly used in these ventilators. However, this technique leads inevitably to excessive oxygen exposure which, in turn, can have deleterious effects on the respiratory tract and organism.

The objective of the present study was to compare $\mathrm{pH}$, partial pressure oxygen $\left(\mathrm{PaO}_{2}\right)$, partial pressure of carbon dioxide $\left(\mathrm{PaCO}_{2}\right)$, and $\mathrm{PaO}_{2} / \mathrm{FiO}_{2}$ ratio or oxygenation index (OI) in arterial blood of rats ventilated with room air and with pure oxygen.

\section{Methods}

The study was approved by the Ethics Committee on Animals Use, Jundiaí School of Medicine (protocol
246/11) and the experiments were conducted at the Laboratory of Surgical Techniques, FMJ.

Twenty adult male Wistar rats (Rattus norvegicus albinus), weighing 306 to $418 \mathrm{~g}$ and ranging in age from 60 to 90 days, were studied. The animals were kept on a $12 \mathrm{~h}$ light/12 h dark cycle, with standard chow and water available ad libitum. These conditions were used as the basis for adaptation.

The animals were divided into two groups of ten animals each: a group ventilated with cylinders of compressed oxygen (oxygen group) and a group ventilated with compressed room air (air group). The conditions of adaptation and care before and after the procedures, as well as the anesthetic technique, tracheal cannulation, heart monitoring, pulse oximeter, blood sample collection, and postoperative care were the same for the two groups.

\section{Anesthesia and monitoring}

After subcutaneous administration of atropine (ampoules $0.25 \mathrm{mg} / 1 \mathrm{~mL}$, dose $0.02 \mathrm{mg}$ body $/ \mathrm{Kg}$ weight), low doses of acepromazine (Acepran 1\%, Univet, São Paulo, dose of $2 \mathrm{mg} / \mathrm{Kg}$ ) were injected intramuscularly as pre-anesthetic. After this, zolazepam + tiletamina (Zoletil 50, Virbac, São Paulo) was administered intramuscularly at a dose of 0.035 $\mathrm{ml} / \mathrm{Kg}$ body weight after $15 \mathrm{~min}$.

The anterior cervical region was prepared for tracheostomy and the animal was positioned in dorsal decubitus on the surgical table. A longitudinal incision of approximately $1 \mathrm{~cm}$ was made in the skin and the tracheal rings were exposed. For tracheal cannulation, a Solidor N. 14 cannula intravenous catheter (BioMed Healthcare Products Pvt. Ltd., Haryana, India) was introduced and a Takaoka 600 (São Paulo, Brazil) mechanical ventilator was installed. Arterial blood samples were collected from central auricular artery by puncture at 5 and at $60 \mathrm{~min}$ after the beginning of mechanical ventilation. The animals received pressure-controlled, time-cycle mode ventilation (inspiratory/expiratory cycles) and respiratory rate 70 breaths/ min. A peak of inspiratory pressure of 20 
$\mathrm{mmHg}$ and was established and positive end expiratory pressure (PEEP) was not used.

\section{Statistical analysis}

The paired $t$-test was used for the comparison of blood gas parameters at the beginning and end of ventilation in the same animal. Blood gas parameters were compared between the two groups using the Student's $t$-test. A p $<0.05$ was considered to indicate statistical significance.

\section{Results}

Intra-group comparison (oxygen or air group) showed no significant differences in blood $\mathrm{pH}, \mathrm{PaO}_{2}$ or $\mathrm{PaCO}_{2}$ after 5 and $60 \mathrm{~min}$ of mechanical ventilation.

Mean blood $\mathrm{pH}$ and $\mathrm{PaCO} 2$ values were similar in the room air and oxygen groups after 5 and $60 \mathrm{~min}$ of mechanical ventilation. In contrast, mean $\mathrm{PaO}_{2}$ values differed significantly between the oxygen and compressed air groups at 5 and $60 \mathrm{~min}$ of mechanical ventilation, with the observation of important hyperoxia in the group ventilated with pure oxygen (5 min: $\mathrm{p}<0.001$ and $60 \mathrm{~min}: \mathrm{p}<0.002$ ) (Table 1).

\begin{tabular}{|c|c|c|c|c|}
\hline \multirow[t]{2}{*}{ Table 1} & \multicolumn{4}{|c|}{$\begin{array}{l}\text { Comparison of } \mathrm{pH}, \mathrm{PaO}_{2}, \mathrm{PaCO}_{2} \text { and } \\
\text { oxygenation index, at the beginning and at } \\
\text { end of artificial ventilation in animals } \\
\text { ventilated with room air and pure oxygen - } \\
\text { Jundiaí, SP, Brazil - } 2013\end{array}$} \\
\hline & & Air group & $\begin{array}{c}\text { Oxygen } \\
\text { group }\end{array}$ & $p$ \\
\hline \multirow{2}{*}{$\mathrm{pH}$} & $5 \mathrm{~min}$ & $7.35 \pm 0.07$ & $7.30 \pm 0.10$ & NS \\
\hline & $60 \mathrm{~min}$ & $7.26 \pm 0.11$ & $7.28 \pm 0.05$ & NS \\
\hline \multirow{2}{*}{$\mathrm{PaO}_{2}$} & $5 \mathrm{~min}$ & $86.1 \pm 31.9$ & $189.4 \pm 50.1$ & $<0.001$ \\
\hline & $60 \mathrm{~min}$ & $93.8 \pm 32.2$ & $227.4 \pm 86.6$ & $=0.002$ \\
\hline \multirow{2}{*}{$\mathrm{PaCO}_{2}$} & $5 \mathrm{~min}$ & $34.9 \pm 10.0$ & $49.5 \pm 11.9$ & NS \\
\hline & $60 \mathrm{~min}$ & $34.6 \pm 8.4$ & $43.4 \pm 10.5$ & NS \\
\hline \multirow{2}{*}{$\mathrm{PaO}_{2} / \mathrm{FiO}_{2}$} & $5 \mathrm{~min}$ & $456 \pm 88$ & $189 \pm 50$ & $<0.001$ \\
\hline & $60 \mathrm{~min}$ & $488 \pm 64$ & $226 \pm 86$ & \\
\hline
\end{tabular}

Values are the mean \pm standard deviation

$P<0.05$; Paired $t$-test; NS: not significant

The mean oxygenation index $\left(\mathrm{PaO}_{2} / \mathrm{FiO}_{2}\right)$ was significantly higher in the compressed air group compared to the oxygen group at 5 and $60 \mathrm{~min}(5$ min: $\mathrm{p}<0.001$ and 60 min: $\mathrm{p}<0.002)$.

\section{Discussion}

Mechanical ventilation of laboratory animals continues to be a matter of discussion. A lot of mechanical ventilators used in research laboratories do not possess blenders. As a consequence, a cylinder of pure oxygen is used as the ventilating gas for artificial ventilation of laboratory animals. However, this technique leads inevitably to excessive $\mathrm{O}_{2}$ exposure which causes cell damage and, to avoid this, the present study aimed to answer two questions: 1) Can rats be ventilated only with room air? 2) If positive, are the blood gas parameters more adequate than those seen in animals ventilated with pure oxygen? Based on results of the present study, the answer to the two questions is yes, and the initial concern that animals ventilated with room air may present hypoxia was not confirmed, with the observation of adequate $\mathrm{PaO}_{2}$ levels in this group.

Table 1 shows the lack of significant differences in $\mathrm{pH}, \mathrm{PaO}_{2}$ and $\mathrm{PaCO}_{2}$ values between the beginning and end of mechanical ventilation in animals ventilated with pure oxygen. However, some deleterious effects have already been triggered and they can be detected through $\mathrm{PaO} 2 / \mathrm{FiO} 2$ ratio in the present study. High concentration of oxygen is a known cause of iatrogenic effects on lung parenchyma and time of exposure seems to be a crucial factor in the process of hyperoxia-induced lung injury (VALENÇA et al., 2004). Andrade et al. (2014) show that although using short-term control mechanical ventilation with protective low tidal volume, hyperoxia has great impact on increasing inflammation and on decreasing diaphragmatic contractile function in rats. Another established mechanism is that hyperoxia induces cytokine production, neutrophil influx, and apoptotic and nonapoptotic epithelial cell injury (LI et al., 2007). High level of oxygen amplifies the expression of acute phase cytokines/chemokine in rats (KROON et al., 2010) even if low tidal volume is used. Hyperoxia may impair the structure and function of alveolar epithelial 
tight junctions and those changes are enhanced with prolonged hyperoxia exposure, which can increase bronchoalveolar permeability and pulmonary edema (YOU et al., 2012). Also, hyperoxia exposure causes predominant effects of inducible nitric oxide synthase and thereby contributes to extend the acute hyperoxic lung injury (HESSE et al., 2004). Decrease of pulmonary compliance, edema, remodeling and inflammation can be produced by hyperoxia (LI et al., 2004).

In the present study, values of $\mathrm{pH}, \mathrm{PaO} 2$ and $\mathrm{PaCO} 2$ did not change either when room air was used in ventilation for $60 \mathrm{~min}$ (Table 1). Also $\mathrm{Li}$ et al. (2004) and Brock and Di Giulio (2006) did not find any statistical difference in these three parameters in the beginning versus five hours of room air mechanical ventilation. That data suggests that mechanical ventilation with room air is safe at least in short and midterms.

A comparison between groups shows that $\mathrm{PaO} 2$ in the beginning and end of mechanical ventilation leads to hyperoxia in animals of oxygen group (Table 1). The ratio between $\mathrm{PaO}_{2}$ and $\mathrm{FiO}_{2}$, also called oxygenation index (OI), is a simple and easy-tomeasure parameter that can be used to quantify pulmonary dysfunction. A significantly higher OI was observed in the room air group compared to the oxygen group, according with methodology used in this current study. Sinclair et al. (2004) found that over time there was a significant divergence in $\mathrm{PaO} 2 / \mathrm{FiO} 2$ ratio between the group ventilated with room and with high level of $\mathrm{O} 2 . \mathrm{PaO} 2 / \mathrm{FiO} 2$ ratio was lower in the hyperoxic group over time with a greater difference in 4-hour measurement. Gas exchange impairment in the group with hyperoxia correlated with greater histology evidence of lung injury in their study. Our results are indicative of pulmonary dysfunction ( OI < 200), which could suggest damage to the alveolar-capillary membrane, even during the short period (60 min). However, since a histological study was not performed to confirm this assertive, this hypothesis cannot be confirmed.
The deleterious effects of hyperoxia have already been proven by other studies and it is not the focus of the current study, but if the cylinder of compressed air is only used for short periods of time (60 $\mathrm{min}$, in this study), it is adequate to ventilate rats. This is indicated by the finding that $\mathrm{pH}, \mathrm{PaO}_{2}, \mathrm{PaCO}_{2}$ and oxygenation index values were within the normal range in the group ventilated with room air. This fact is important for researchers in studies performed in rats' chest when pneumothorax always occurs since the chest cavity is open. Thus, the need to ventilate these animals mechanically becomes necessary to avoid death from lung expansion due to pneumothorax. As cited before, hyperoxia also promotes lung dysfunction by leading to local and systemic inflammation and if the researcher is utilizing inflammatory or anti-inflammatory markers, misinterpretation of the results could happen.

\section{Conclusions}

In this experimental study, the mechanical ventilation of rats with a cylinder of compressed air seems to be more adequate than ventilation with a cylinder of oxygen, because it can prevent the hyperoxia observed with the latter. In addition, ventilation with air may protect the alveolar-capillary membrane, with the observation of a better $\mathrm{PaO}_{2} / \mathrm{FiO}_{2}$ ratio when compared to oxygen ventilation. Moreover, air is less costly and more easily accessible compared to oxygen.

\section{Author Contributions}

Carvalho MVH, concept and design of study, performed the procedures, manuscript writing, critical revision. Fruchi AJ, performed the procedures, acquisition and analysis of data. Marchi E, acquisition and analysis of data and critical revision. 


\section{References}

ANDRADE, P.; SANTOS, J. M.; SILVA, H. C. A.; WILBERT, D. D.; CAVASSANI, S. S.; OLIVEIRAJÚNIOR, I. S. Influence of hyperoxia and mechanical ventilation in lung inflammation and diafragma function in aged versus adult rats. Inflammation, v. 37, n. 2, p. 486494, 2014. doi: 10.1007/s10753-013-9762-4.

BROCK, T. G.; DI GIULIO, C. Prolonged exposure to hyperoxia increases privascular mast cells in rat lungs. Journal of Histochemistry and Cytochemiistry, v. 54, n. 11, p. 1239-1246, 2006. doi: 10.1369/jhc.6A7007.2006.

HEDENQVIST, P. Anesthesia and analgesia for surgery in rabbits and rats: a comparison of different compounds. 2008. 48 f. Tese (Doutorado) - Department of Physiology and Pharmacology, Karolinska Institute, Stockholm, 2008.

HESSE, A. K.; DÖRGER, M.; KUPATT, C.; KROMBACH, F. Proinflammatory role of inducible nitric oxide synthase in acute hyperoxic lung injury. Respiratory Research, v. 5, n. 11, p. 1-9, 2004. doi: 10.1186/1465-9921-5-11.

KROON, A. A.; WANG, J.; HUANG, Z.; CAO, L.; KULISZEWSKI, M.; POST, M. Inflammatory response to oxygen and endotoxin in newborn rat lung ventilated with low tidal volume. Pediatric Research, v. 68, n. 1, p. 63692, 2010. doi: 10.1203/PDR.0b013e3181e17caa.

LI, L. F.; LIAO, S. K.; KO, Y. S.; LEE, C. H.; QUINN, D. A. Hyperoxia increases ventilator-induced lung injury via mitogen-activated protein kinases: a prospective, controlled animal experience. Critical Care, v. 11, n. 1, p. 1-14, 2007. doi:10.1186/cc5704.

LI, L. F.; YU, L.; QUINN, D. A. Ventilation-induced neutrophil infiltration depends on c-Jun N-terminal kinase. American Journal of Respiratory and Critical Care Medicine, v. 169, n. 4, p. 518-524, 2004. doi: 10.1164/rccm.200305-660OC.

O'NEIL; B. J.; KLINE, J. A.; BUKHART, K.; YOUNGER, J. Research fundamentals: V. the use of laboratory animal models research. Academic Emergency Medicine, v. 6, n. 1, p. 75-82, 1999.

SINCLAIR, S. E.; ALTEMEIR, W. A.; MATUTE-BELLO, G.; CHI, E. Y. Augmented lung injury due to interaction between hyperoxia and mechanical ventilation. Critical Care Medicine, v. 32, n. 12, p. 2496-2501, 2004. doi: 10.1097/01.CCM.0000148231.04642.8D.

VALENÇA, S. S.; KLOSS, M. L.; BEZERRA, F. S.; LANZETTI, M.; SILVA, F. L.; PORTO, L. C. Efeitos da hiperóxia sobre o pulmão de ratos Wistar. Jornal Brasileiro de Pneumologia, v. 33, n. 6, p. 655-662, 2004. doi: 10.1590/S1806-37132007000600008.

YOU, K.; XU, X.; FU, J.; XU, S.; YUE, X.; YU, Z.; XUE, X. Hyperoxia disrupts pulmonary epithelial barrier in newborn rats via the deterioration of occludin an ZO-1. Respiratory Research, v. 13, n. 1, p. 36-46, 2012. doi: 10.1186/1465-9921-13-36. 